\title{
IMMUNOCHEMICAL STUDIES ON HUMAN SEMINAL PLASMA
}

\author{
II. THE MAJOR ANTIGENS AND THEIR FRACTIONATION \\ SIDNEY SHULMAN* AND PAUL BRONSON \\ Department of Microbiology, School of Medicine, \\ State University of New York, Buffalo, New York
}

(Received 29th April 1968)

\begin{abstract}
Summary. It was found that human seminal plasma contained a large number of antigenic components as tested with selected antiserum bleedings from rabbits that had been intensively immunized with pooled seminal plasma. Gel diffusion experiments revealed a total of eight to eleven distinctive components, although several experiments had to be considered jointly to achieve unambiguous resolution. These experiments included variations in the concentration of the seminal plasma and the spacings between the wells.

Immuno-electrophoresis gave a clearer resolution. A characteristic pattern of twelve components was seen, consisting of four major mobility groups of antigens with high diffusion rates and two other mobility groups with low diffusion rates. These were termed $A, B_{1}, B_{2}, C_{1}, C_{2}, C_{3}, D_{1}$, $D_{2}, E_{1}, E_{2}, F_{1}$ and $F_{2}$. It was further shown that serum albumin was one of the components in seminal plasma (component $\mathrm{A}$ ).

It was also found that the predominant electrophoretic component could be isolated by starch block electrophoresis, and that this corresponded to component $\mathrm{C}_{2}$ of the immuno-electrophoretic pattern.
\end{abstract}

\section{INTRODUCTION}

The constituents of seminal plasma have been long known to be highly antigenic. Thus, there have been many descriptions of antibody response in an animal that was injected with semen or seminal plasma originating from a different species of animal. A few recent reports on human seminal plasma can be cited as examples (Hermann, 1960; Klopstock, Haas \& Rimon, 1963; Searcy, Craig \& Bergquist, 1964; Behrman \& Amano, 1967; Pikó, 1967). These studies involved the formation of a particular form of antibody, that is, heteroantibody. Although Rümke $(1954,1965)$ and others (Wilson, 1954; Rümke \& Hellinga, 1959), have shown that autoantibodies to semen can occur in the human, these antibodies are directed against sperm cells, and there

* Present address: Department of Microbiology, New York Medical College, New York, N.Y. 10029 . 
has been no evidence, so far, that autoantibodies against antigens of the seminal plasma occur in man. On the other hand, it was shown quite recently that rabbits can be immunized to produce autoantibodies against components of rabbit seminal plasma (Riera, Yantorno \& Shulman, 1967; Shulman, Riera \& Yantorno, 1968). It has, therefore, become of increased interest to explore more thoroughly the possible role of human seminal plasma as an autoantigenic stimulus. For this eventual goal, more should first be learned about the diverse antigenic constituents of human seminal plasma (HSP). The multiplicity of protein components contained in this fluid needs further sorting out, and the individually defined substances should then receive more precise characterization.

Earlier studies have emphasized the intensive proteolytic activity that occurs in human seminal plasma (Shulman \& Bronson, 1968). It was found, however, that a split ejaculate provided two fractions that were each quite stable. One of these could then be used as a starting material for isolation of the major protein component. This was a second part of the present work, leading toward the characterization of this major constituent as an antigen and as a protein.

\section{MATERIALS AND METHODS}

Semen samples were provided by normal donors. The specimen was chilled immediately and kept at $4^{\circ} \mathrm{C}$ for no longer than $10 \mathrm{hr}$, and was centrifuged at $10,000 \mathrm{rev} / \mathrm{min}$ for $10 \mathrm{~min}$. The clear, opalescent supernatant was used immediately, or stored at $-20^{\circ} \mathrm{C}$ until needed. Protein determination was by a biuret method (Gornall, Bardawill \& David, 1949), using an extinction coefficient of $2 \cdot 2$, determined on a pool of normal human seminal plasma.

Three New Zealand White rabbits were injected with pooled seminal plasma over a 14-month period. A total of 15 to $30 \mathrm{mg}$ of the antigen was thus incorporated into complete Freund's adjuvant and injected subcutaneously in the inguinal region of each rabbit. Initially, the adjuvant was fortified by the addition of $6 \mathrm{mg} / \mathrm{ml}$ of killed $M$. butyricum. In each subsequent inoculation, this was reduced by $2 \mathrm{mg} / \mathrm{ml}$, until a level of an incomplete adjuvant was reached.

Trial bleedings were usually taken before each injection, and the final bleeding was taken about 1 week after the last injection. These bleedings were evaluated for strength and diversity of response by immunodiffusion reactions of several types.

The fundamental immunodiffusion method was patterned after that of Ouchterlony (1958), using $1 \%$ agar in $0.15 \mathrm{~m} \mathrm{NaCl}$. The configuration consisted of a central well, $3 \mathrm{~mm}$ in diameter, surrounded by $3-\mathrm{mm}$ wells that were spaced from the central well at an edge-to-edge distance of either 3 or $5 \mathrm{~mm}$. After charging the wells, diffusion was allowed to proceed at room temperature, in most instances, for 24 to $48 \mathrm{hr}$. In some studies, the procedure was conducted at $4^{\circ} \mathrm{C}$.

Immuno-electrophoresis was carried out as described by Scheidegger (1955), using a barbital-acetate buffer at $\mathrm{pH} 8 \cdot 6$ (Crowle, 1961). Except for the earliest 
experiments, the electrophoresis was conducted for $2 \mathrm{hr}$, rather than the usual 3 , to eliminate the risk of losing the most cathodically migrating species. The measured electric field strength on the slide was 6.5 volts $/ \mathrm{cm}$. At the termination of electrophoresis, the troughs were filled with the appropriate antiserum in some instances, or with dilutions of antigen when Osserman-type reactions (Osserman, 1960) were desired. The shorter length of time for the electrophoretic migration also resulted in sharper precipitin arcs as a consequence of a lessened dilution of the zones of protein.

Starch block electrophoresis was performed essentially as described by Shulman, Rapp, Bronson \& Arbesman (1962), with some modification. The sample slot was cut $20 \mathrm{~cm}$ from the cathode end of the block to allow greater resolution of the cathodic components. A slurry composed of $1.8 \mathrm{ml}$ of fraction 2 from a split ejaculate (Shulman \& Bronson, 1968), that had been mixed with dry starch, was poured into the sample slot. The block was eluted after termination of the run, without prior freezing.

\section{RESULTS}

\section{Gel diffusion analysis}

Tests of gel precipitation were set up between samples of seminal plasma and various bleedings from the rabbits. One of the rabbits (2276) gave very poor results, in all its bleedings. The antiserum samples from the other two rabbits were used extensively. Many lines of precipitation were seen, depending on the serum used. Many of the studies were done with R 2278-final, in order to study as many components as possible, although some earlier bleedings were also tested, in order to seek a more specific antiserum. The third rabbit, $\mathbf{R} 2277$, did not ever develop as strong or multiple a response as the other animal.

Because of the studies that have revealed changes in electrophoretic patterns with time of storage (Shulman \& Bronson, 1968; Schneider, 1955), it was felt that some risk was involved in performing gel diffusion in the customary manner, that is, incubation at room temperature for 1 or more days. Therefore, results were compared in duplicate gel diffusion plates placed at room temperature $\left(20\right.$ to $\left.21^{\circ} \mathrm{C}\right)$ and cold room temperature $\left(4^{\circ} \mathrm{C}\right)$. In addition, duplicate plates were prepared at each of these temperatures, in which the $3-\mathrm{mm}$ wells were spaced at either $3 \mathrm{~mm}$ or $5 \mathrm{~mm}$ apart. It was found from a number of such experiments that the pattern of precipitation was essentially the same at both temperatures, indicating that no problem of significant (or detectable) degradation of seminal antigens occurred under these conditions.

Each of these antisera also gave precipitation with normal human serum and, in fact, revealed several such lines of reaction, thus indicating clearly the presence of a number of serum components or serum-like components in the seminal plasma which had been used for immunization. The exact number of cross-reacting components that was indicated varied with the individual rabbit and with the particular bleeding; in addition, the indicated number of lines varied considerably with the geometry of the arrangement of wells. This point is strikingly demonstrated in Pl. 1, Fig. 1, where R 2278-final has been tested 
against a series of dilutions of human seminal plasma and also against a sample of human serum. The antigens of serum can be considered first. In the pattern with wells separated by $5 \mathrm{~mm}$, only three lines are seen (well 6), two of which are very broad smudges. On the other hand, in the pattern with wells separated by $3 \mathrm{~mm}$, these two broad lines revealed themselves to be groups of two or three lines each, giving a total of six lines for serum, if one also includes the central sharp line from the 5-mm pattern. With regard to the analysis of the seminal plasma itself, it is of the greatest importance to examine this material at several different dilutions, as well as geometric spacings, for it is clear that the number of lines, ignoring serum lines, is quite different under these varying conditions. It can be seen for the two respective patterns of Pl. 1, Fig. 1, that at the highest concentration of seminal plasma (well 1) there are five or eight lines of precipitation, but that some of these fade out at lower concentrations, while other lines appear which cannot be resolved at the higher concentrations. In this way, additional lines are seen (well 3, for example) which clearly indicate two or three additional antigenic components. This finally suggested a total of eight to eleven distinctive components. The influence of well spacing will be discussed below.

\section{Immuno-electrophoretic analysis}

The use of the more potent antiserum, $\mathrm{R} 2278$, revealed as many as eleven or twelve distinctive arcs. Although the exact number and appearance of these precipitating components varied somewhat from one sample to another, numerous experiments of this sort could be analysed to reveal a rather typical fundamental pattern of precipitation, which is illustrated as a schematic diagram in Pl. 1, Fig. 2. It can be seen that there is an assembly of long arcs which are approximately the same short distance from the antibody trough, but which have widely different mobilities. These major arcs are indicated by letters $\mathrm{A}$, $\mathbf{C}, \mathbf{E}$ and $\mathbf{F}$. The lines for $\mathbf{C}$ and $\mathbf{E}$ are actually seen to be, in fact, multiple components with very similar mobilities, and these are distinguished as $\mathrm{C}_{1}, \mathrm{C}_{2}$, $\mathrm{G}_{3}$ and $\mathrm{E}_{1}, \mathrm{E}_{2}$. A faint additional line is frequently seen in the F-region, and so one should also refer to $F_{1}$ and $F_{2}$. In addition to these eight components, there are several lines which are located at a much greater distance from the antibody trough, and which correspond to two principal mobility categories, which are located near the fast and slow ends, respectively, of the $\mathrm{C}$ group of arcs. These have, therefore, been designated as the B and D groups, and the individual components of each of these groups have been differentiated by subscript numbers. Since one can usually detect two members of each of these minor groups, it can be concluded that there is a minimum number of reproducibly detected components equal to twelve. To illustrate the small differences that can occur, a group of four similar immuno-electrophoretic runs is shown in Pl. 2, Fig. 3, wherein each run is on a different sample of seminal plasma. The variations might be ascribed to individuality of the sample, but perhaps more likely are due to the age of the sample, thus reflecting the various degradation processes that can occur in these materials with storage.

Some of these components are clearly related to serum proteins, but only one of them is conspicuous in this regard, and this is component $\mathrm{A}$, which seems to 

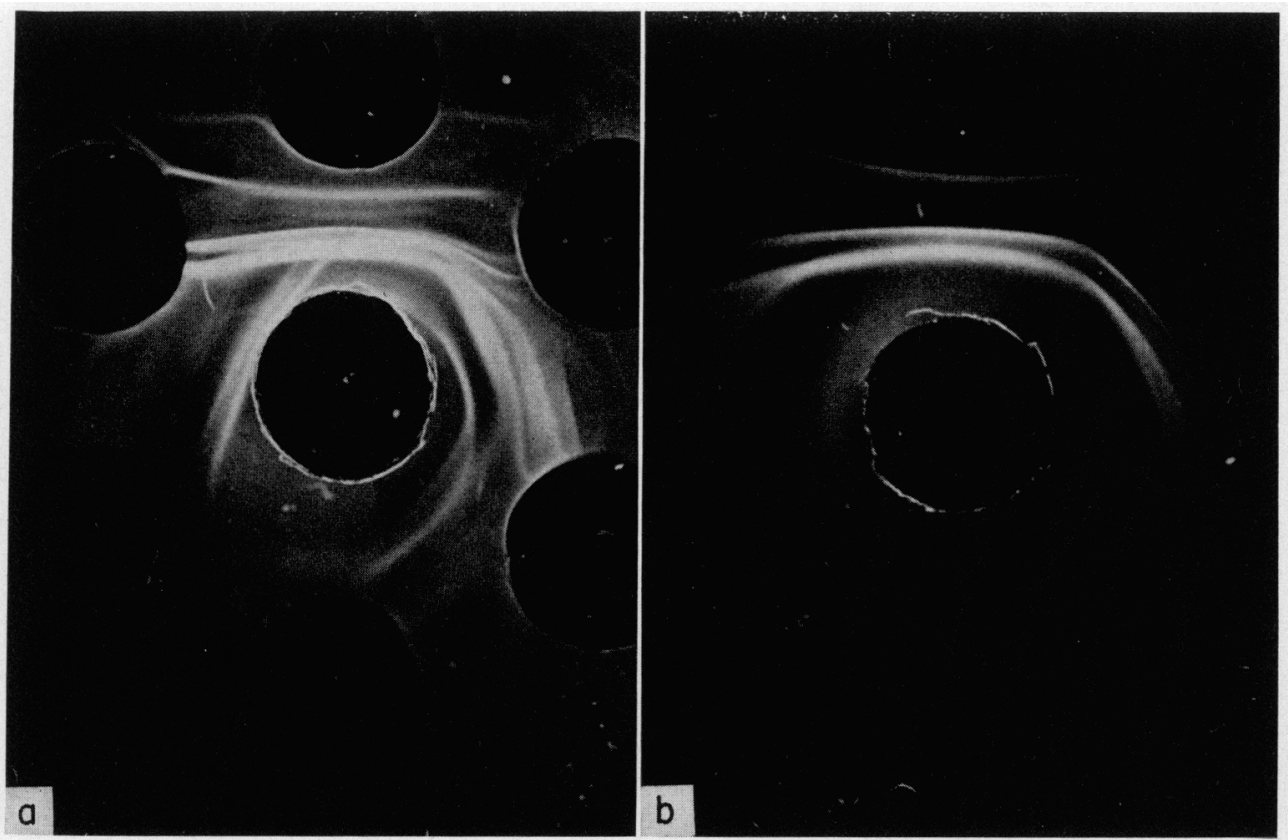

Fig. 1. Gel diffusion precipitation pattern. (a) Wells are $3 \mathrm{~mm}$ in diameter, $3 \mathrm{~mm}$ apart; (b) wells are $3 \mathrm{~mm}$ in diameter, $5 \mathrm{~mm}$ apart. Centre well: rabbit serum 2278-final; peripheral wclls: clockwise from top: (1) human seminal plasma, at a $1: 5$ dilution (protein concentration, $9 \mathrm{mg} / \mathrm{ml}$ ), (2) same sample, at a 1:25 dilution, (3) same sample, at a 1:125 dilution, (4) same sample, at a 1:625 dilution, (5) same sample, at a 1:312.5 dilution, (6) human scrum, at a $1: 5$ dilution (protein concentration, $14 \mathrm{mg} / \mathrm{ml}$ ).

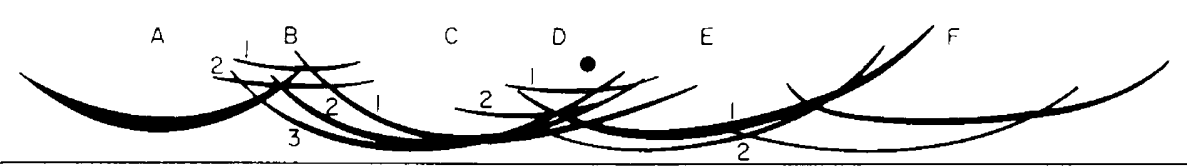

FIG. 2. Idealized sketch of immuno-electrophoresis pattern for human seminal plasma anaiysed by rabbit serum. The distinguishable component arcs are labelled. 
PL, \TF, 2
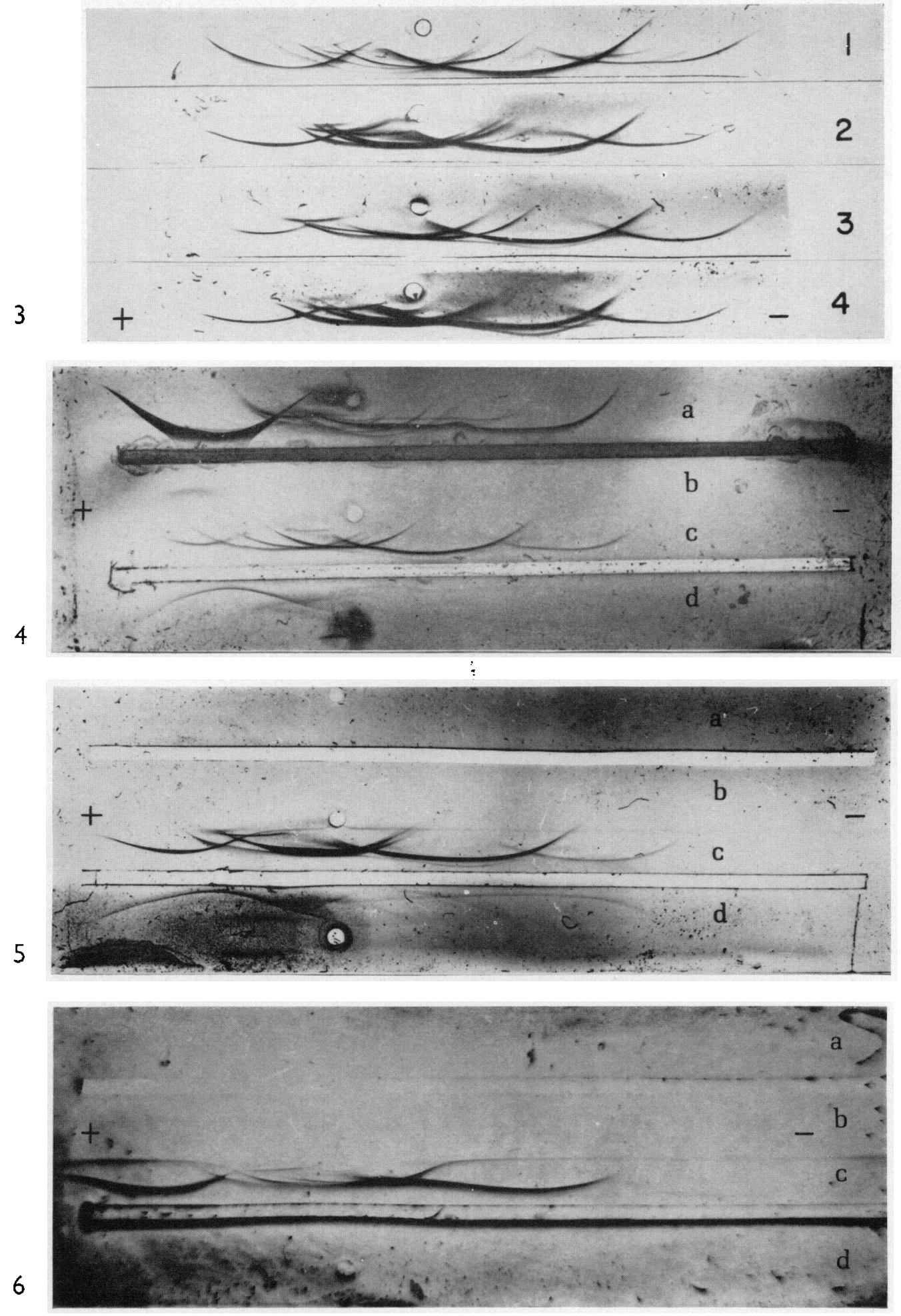
be identical to serum albumin. This can be seen immediately by two types of experiment, both of which are illustrated in Pl. 2, Fig. 4 where the pattern of the seminal plasma components (on yet another individual sample) in track $\mathrm{c}$ is paralleled by the analysis of human serum in track d. One strong and definite line was seen for the serum, and this was located in the albumin-mobility region; there were perhaps one or two very faint additional lines, which were located around the $\alpha_{2}$-globulin position. Tracks $\mathrm{a}$ and $\mathrm{b}$ represent tests with antiserum $\mathrm{R} 64$, an antiserum against human serum. Track a gives the reference serum pattern while track $\mathrm{b}$ again shows a definite arc, of somewhat broad nature, that seems to be in the albumin-mobility region. Finally, definite evidence as to the albumin nature of this fast component can be obtained by an experiment according to the method of Osserman (1960). This is shown in Pl. 2, Fig. 5, where the upper trough contained $0.01 \%$ human serum albumin, and the lower trough contained the usual R 2278. A horizontal line of precipitation is seen between the troughs; it results from the migration of the known serum albumin towards its corresponding antibody in the R 2278, and it shows a perfect and complete reaction of fusion with the arc that has been designated component $\mathrm{A}$ in the pattern for seminal plasma components.

\section{Fractionation by zone electrophoresis}

Starch block electrophoresis was applied to several samples of seminal plasma, using samples that were second fractions in split ejaculates. Text-fig. 1 shows one of the protein elution curves from such a separation. There is an apparent resolution into about six peaks, and these have been arbitrarily designated fractions 1 to 6 . Fraction 3 is the major component and only this fraction has been further studied in any detail. The distribution of yields is shown in Table 1.

The minor components were pooled as fractions of either faster or slower mobility values than fraction 3 , and they were subjected to some comparative studies, but the yields of materials were inadequate for definitive evaluation. Fraction 3, however, was analysed repeatedly, and it was found to be a much more homogeneous product than the original whole seminal plasma, as judged by filter paper electrophoresis, analytical ultracentrifugation, and especially by gel diffusion analysis. The ultracentrifugal results are reported in a later paper of this series, but it can be stated here that a single component was seen, with no sign of faster peaks at the concentration at which the protein was studied; a similar concentration of protein for whole seminal plasma reveals

\section{EXPLANATION OF PLATE 2}

FIG. 3. Immuno-electrophoresis patterns for four individual samples of human seminal plasma. Both antiserum troughs contain rabbit serum 2278-final.

FIG. 4. Immuno-electrophoresis. Tracks a and d, human serum; tracks b and c, human seminal plasma. Upper trough: rabbit anti-human serum (R64). Lower trough: rabbit anti-human seminal plasma (R 2278).

FIG. 5. Immuno-electrophoresis. Tracks a and b, empty; track c, human seminal plasma; track $d$, human serum. Upper trough: human serum albumin, at $0.01 \%$. Lower trough: rabbit anti-human seminal plasma ( $R$ 2278).

Frg. 6. Immuno-electrophoresis. Track a, empty; tracks b and c, human seminal plasma; track d, fraction 3 from starch block run 161 , at $0.13 \%$. Upper trough: fraction 3 from starch block run 161 , at $0 \cdot 13 \%$. Lower trough: rabbit anti-human seminal plasma (R 2278). 
several faster sedimenting components. This single sedimenting peak had a sedimentation coefficient of $1.0 \mathrm{~S}$.

The gel diffusion analysis of homogeneity was performed in such a way that it would also afford an identification of this isolated component among the

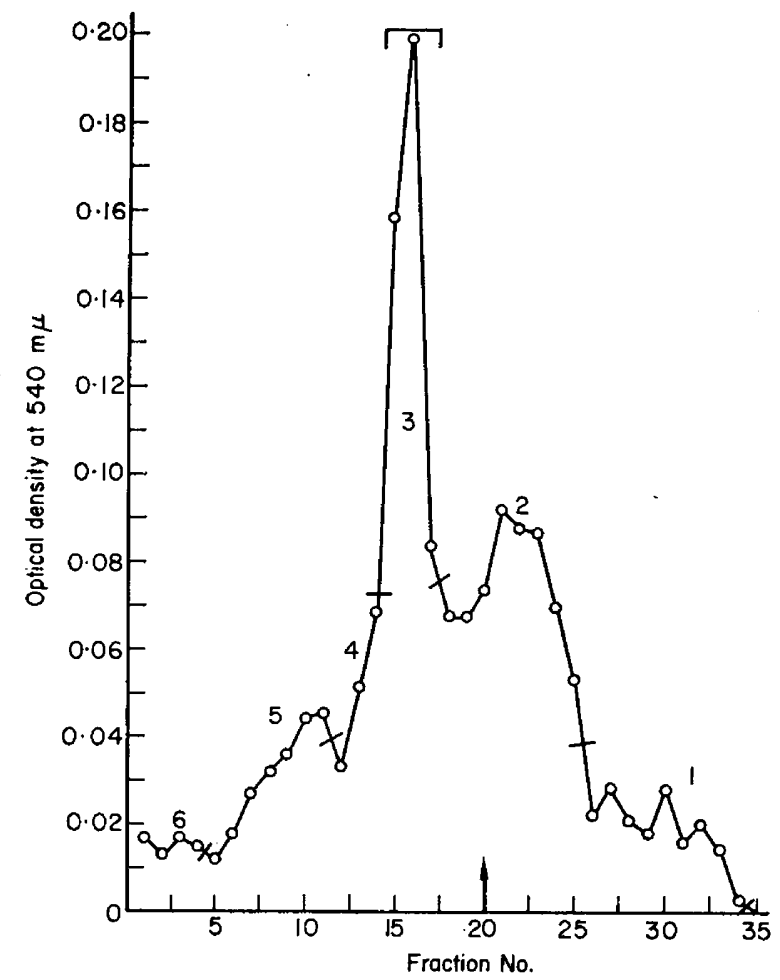

TEXT-FIG. 1. Elution pattern (biuret readings) from starch block electrophoresis of human seminal plasma (run 161).

TABLE 1

DISTRIBUTION OF PROTEINS IN THE FRACTIONS FROM STARCH BLOCK ELECTROPHORESIS OF HUMAN SEMINAL PLASMA

\begin{tabular}{l|c|c|c|c}
\hline \multicolumn{1}{c|}{ Fraction } & Vol. $(d l)$ & Conc. $(g / d l)$ & Amount $(g)$ & $\begin{array}{c}\% \\
\text { Recovery* }\end{array}$ \\
\hline Initial sample & 0.020 & 5.43 & 0.11 & - \\
$1+2$ & 0.31 & 0.15 & 0.046 & 41.8 \\
3 & 0.050 & 0.35 & 0.018 & 16.4 \\
4 & 0.064 & 0.08 & 0.005 & 4.5 \\
$5+6$ & 0.056 & 0.06 & 0.003 & 2.7 \\
\hline
\end{tabular}

* Total \% recovery 65.4 .

group of characteristic precipitating components seen in the immuno-electrophoretic pattern that has been established. Accordingly, an experiment was done by the method of Osserman, and the results are illustrated in Pl. 2, Fig. 6. It can be seen that a single horizontal line of precipitation has resulted from the 
diffusion of the fraction from the upper trough towards the antiserum in the lower trough. Secondly, this straight line shows a deviation into an arc at the points of merger with component $\mathrm{C}_{2}$ (or possibly $\mathrm{C}_{1}$ ) of the total pattern of electrophoretic antigenic distribution.

\section{DISCUSSION}

Many studies in the past have emphasized the heterogeneity of human seminal plasma. The major group of reports has been based on one form or another of zone electrophoresis, most commonly on filter paper (Schneider, Nowakowski \& Voigt, 1954; Schneider, 1955; Keller \& Tschumi, 1953; Raboch, 1961; Rozin, Graff \& Shafrir, 1963; Hermann, Licht, Keutel \& Krug, 1958; Paolella, 1957; Fiala \& Raboch, 1958; Shulman \& Bronson, 1968). The heterogeneity can also be evaluated by means of antigenic analysis, and this approach has now been followed, using hyper-immunized rabbit antisera. While several reports have appeared in recent literature on the analysis of human seminal plasma by the use of antisera, a number of reports suffer from technical or theoretical problems. Apparently it has not always been fully realized that not every immunized animal will produce as full a collection of antibody responses, and the use of only a single antiserum against each antigenic material has led to inadequate studies. Secondly, it is often not realized that various bleedings from the same animal, taken at various times after injection, would also vary in the degree and the variety of antibody responses. Thirdly, the extent of antibody response to components of blood serum and to components that are common to other tissues of the body has not always been studied. In addition to these theoretical problems, there have been only limited efforts to study variations of concentration of seminal plasma or of antiserum, as well as the geometry, time of incubation, and temperature. In some reports, commercial antisera have been obtained with no subsequent study as to the sensitivity or the degree of specificity of these reagents.

In our study, one of the rabbits responded much more poorly than the other two and between these two, one was somewhat superior in the number of reactions that could be detected. This animal was therefore selected for the bulk of the examinations. It was also observed that, in this animal, the earlier bleedings were more highly specific in that very little response to human serum proteins was obtained; however, the number of responses to seminal plasma components was more limited in the early bleedings and therefore the final bleeding was bound to be the most satisfactory for our purposes. It should be emphasized that the final bleeding obtained after a series of injections need not necessarily be the most satisfactory, since the increased response to minor components from serum might create problems in interpretation.

Because of the intensive proteolytic activity in human seminal plasma during storage, even at reduced temperatures, it was felt that gel diffusion experimentation might suffer from modifications of the protein components during the very process of migration and interaction of the constituents. It was found, however, that the pattern of precipitation was essentially the same for the experiments incubated at $4^{\circ} \mathrm{C}$ and those incubated at about $20^{\circ} \mathrm{C}$. We would 
conclude that there probably was appreciable degradation of some components, but that this could not be detected by the means employed. It must be emphasized that immunochemical precipitation is a very sensitive procedure for the detection of antigen and that nearly the same degree of visible precipitation would be seen for an antigen that may have been considerably reduced in its level of concentration. Be that as it may, one can analyse the seminal plasma without concern for this temperature-of-storage problem.

Additional comparisons were made utilizing different geometric spacings between the antigen and antibody wells. The comparisons indicated clearly that the precipitation pattern is so complex that one must choose between the extremes of losing some lines because of too great a spacing, or of having too many lines crowded and superimposed because of too close a spacing. A total of ten or eleven distinctive components was judged to be present. The human serum precipitated to show about six lines, although one or two of these were very weak and thus would seem to indicate extremely dilute components. It is not to be concluded that all six of these components will be detected in a significant amount in each seminal plasma to be examined. The antibody responses need only exist because of immunization with pools of seminal plasma material. Individual humans may differ in the complete set of serum components to be found in their seminal plasma.

This type of specificity analysis can be done more favourably by means of immuno-electrophoresis. After studying a number of such experiments, it was realized that a fairly typical pattern could be detected. This fundamental pattern consists of a group of long arcs lined up somewhat like a fleet of galleys, representing four different mobility categories at similar diffusion distances. These four major arc groups have been designated A, C, E and F. Since the two centre ones are always multiple arcs containing components with very similar mobilities, and since the individual components in each group are not always seen in every sample, they have been distinguished by subscripts as $\mathrm{C}_{1}, \mathrm{C}_{2}, \mathrm{C}_{3}$, and $E_{1}, E_{2}$. The $F$-region often shows a main $F$ and a weaker $F_{2}$. One, therefore, has eight components of long migration distance (high diffusion rates) from the line of antigen centres of diffusion. Additionally, there are several lines which are much closer to the antigen axis (low diffusion rates) and which correspond to two major categories of mobility. These were labelled B and D, with some individual components in each group. The total pattern shows twelve components, in general.

It has always been found that at least one component of each major mobility group is invariant, from one sample to the next, so there is always seen to be a characteristic component $A$, one member of $C$, the $E_{1}$, and $F$, for the major components, and usually one member each of the $B$ and $D$. The second component of B, D and E may or may not be seen, and the C group may or may not show its third component. These variations may well be ascribed to the individual source of each sample, and this will require further study for clarification, but at this time it seems quite likely that at least equal emphasis should be placed on the problem of storage and degradation of the materials. Since these patterns, unlike the gel diffusion discussed above, partake of the analysis based on electrophoretic mobility groups, they may well show some reflection 
of the proteolytic lowering of concentration of certain components, and this may quite possibly explain why some samples are deficient in one or another of the standard assembly of constituents.

Additional comments may be made on the number of components of serum origin to be detected in seminal plasma and their identities. One predominant component, reactive with antiserum to human serum, could be detected and was proven by various indirect and direct tests to be serum albumin. Two other faint components could be seen, but more probing tests will be reported in subsequent papers. The occurrence of several antigenic components of serum has been described in seminal plasma by a number of workers. Various total numbers of such components have been claimed, such as four (Searcy et al., 1964), five (Rozin et al., 1963), and seven to ten (Klopstock et al., 1963). There has also been considerable disagreement over the presence of gamma globulin as one of these components, although there has been general agreement that serum albumin is present. The current report adds additional evidence with regard to the location of serum albumin in the samples that have been studied. It is apparent that the definition of the other components of serum will need more detailed study.

In an effort to purify one of the major components of semen, starch block electrophoresis was applied to split ejaculate fractions that were obtained as fraction-2 preparations. The major component was shown to be quite homogeneous ultracentrifugally, in contrast to the initial unfractionated seminal plasma. It had a sedimentation constant of 1.0 which corresponds well with the major component seen for whole seminal plasma. By direct comparison in immuno-electrophoresis, this fraction was shown to correspond to a major component of the $\mathrm{C}$-arc group, most probably $\mathrm{C}_{2}$. Further studies on the nature of this component and of several others are in progress.

A very similar immuno-electrophoretic pattern to that described above was reported by Hekman \& Rümke (1968), as part of a study on the sperm-coating antigen of Weil and others (Weil, Kotsevalov \& Wilson, 1956; Weil \& Finkler, 1958; Weil, 1961). The sperm-coating antigen was definitely shown to be one of the fastest migrating components and not to be the major component, which we have designated here as fraction 3 in the starch block electrophoresis. This major fraction and the sperm-coating antigen fraction are thus of great interest for much further study on purification and characterization, as being possible contenders for the antigenic stimulus involved in autoantibody formation. The various other components must also be analysed as possible alternatives.

A very interesting report has appeared from Halpern, Ky \& Robert (1967), proving that human antibodies against constituents of human seminal plasma can occur. This one case of spontaneous antibody formation to such antigens is not of central import here, because it was a reaginic antibody. However, the very fact that seminal plasma was apparently antigenic by a type of normal iso-immunization indicates that much more investigation must be made on the parameters, genetic and others, that may control the possible formation of nonreaginic antibody to immunization with this material. Some fractionation studies were carried out by these workers, and the allergenic activity was 
associated with a glycoprotein fraction rich in sialic acid, which gave a single immuno-electrophoretic line compared to six lines seen for whole seminal plasma. While the pattern given is difficult to compare to ours with precision, it seems probable that their allergen is found in our group of $\mathrm{E}$ components.

\section{ACKNOWLEDGMENTS}

This study was supported by a grant from the John A. Hartford Foundation, Inc., and by research grant AM-04195 from the National Institute of Arthritis and Metabolic Diseases, U.S. Public Health Service, Bethesda, Md.

One of us (S.S.) was the recipient of a Research Career Award (K6-AI-1377) from the U.S. Public Health Service, Bethesda, Md.

\section{REFERENCES}

Behrman, S. J. \& Amano, Y. (1967) Immunochemical studies on human seminal plasma. I. Antigenicity of seminal protein. Int. 7. Fert. 12, 291.

Crowle, A. J. (1961) Immunodiffusion, p. 303. Academic Press, New York.

FIALA, J. \& RABOCh, J. (1958) Papirová elektroforesa bilkovin v lidském ejakulátu. Čas. Lék. cesk. 97, 240.

Gornall, A. G., Bardawill, C. J. \& David, M. M. (1949) Determination of serum proteins by means of the biuret reaction. $\mathcal{F}$. biol. Chem. 177, 751.

Halpern, B. N., Ky, T. \& Robert, B. (1967) Clinical and immunological study of an exceptional case of reaginic type sensitization to human seminal fluid. Immunology, 12, 247.

Hekman, A. \& RümKe, P. (1968) The specificity of the antigens of human seminal plasma with special reference to lactoferrin as spermatozoa coating antigen. Proc. int. Symp. Immunology of Reproduction and Fertilization, Varna, 1967.

Hermann, G. (1960) Le plasma seminal. In: Analyse Immunoélectrophorètique, p. 271. Ed. P. Grabar and P. Burtin. Masson, Paris.

Hermann, G., Licht, W., Keutel, H. J. \& Krug, E. (1958) Elektrophoretische Untersuchungen am menschlichen Spermaplasma. Z. ges. exp. Med. 130, 436.

Keller, M. \& Tschumi, R. (1953) Elektrophoretische Studien am menschlichen Spermaplasma. Gynaecologia, 135, 92.

Klopstock, A., HaAs, R. \& Rimon, A. (1963) Immunoelectrophoretic analysis of seminal plasma. Fert. Steril. 14, 530.

Osserman, E. F. (1960) A modified technique of immunoelectrophoresis facilitating the identification of specific precipitin arcs. f. Immunol. 84, 93.

Ouchterlony, O. (1958) Diffusion-in-gel methods for immunological analysis. Prog. Allergy, 5, 1.

PAOlella, A. (1957) Elettroforesi su carta di liquido seminale umano normale e patologico. Minerva Med. Leg. 77, 48.

Prkó, L. (1967) Immunological phenomena in the reproductive process. Int. F. Fert. 12, 377.

RaвOCH, J. (1961) Electrophoresis of seminal plasma proteins. Int. 7. Fert. 6, 31.

Riera, C., Yantorno, C. \& Shulman, S. (1967) Antigenic specificity of seminal plasma and the formation of autoantibodies. Fedn Proc. Fedn Am. Socs exp. Biol. 26, 532.

Rozin, S., GrafF, E. \& Shafrir, E. (1963) Electrophoretic resolution and characterization of human seminal plasma proteins. Int. F. Fert. 8, 523.

Rümke, P. (1954) The presence of sperm antibodies in the serum of two patients with oligozoospermia. Vox Sang. 4, 135.

RÜMKE, P. (1965) Autospermagglutinins: a cause of infertility in men. Ann. N.Y. Acad. Sci. 124, 696.

RümKe, P. \& Hellinga, G. (1959) Autoantibodies against spermatozoa in sterile men. Am. F. clin. Path. $32,367$.

ScheidegGer, J. J. (1955) Une micro-méthode de l'immunoélectrophorèse. Int. Archs Allergy appl. Immun. 7, 103.

SchNeIDer, W. (1955) Neue Gesichtspunkte der Spermaelektrophorese. Sympn. dt. Ges. Endokr. 2, 200.

Schneider, W., Nowakowski, K. \& Voigt, K. D. (1954) Die Papierelektrophoreses von menschlichen Spermaplasma. Klin Wschr. 32, 863.

Searcy, R. L., Craig, R. G. \& Bergquist, L. M. (1964) Immunochemical properties of normal and pathologic seminal plasma. Fert. Steril. 15, 1. 
Shulman, S. \& Bronson, P. (1968) Immunochemical studies on human seminal plasma. I. Changes in composition during storage, as demonstrated by electrophoresis. Fert. Steril. 19, 549.

Shulman, S., Rapp, D., Bronson, P. \& Arbesman, C. E. (1962) Immunologic studies of caddis fly. II. Isolation of the allergenic fractions of caddis fly extract. $\mathcal{F}$. Allergy, $33,438$.

Shulman, S., Riera, C. \& Yantorno, C. (1968) Studies on organ specificity. XIX. Antigenic specificity of seminal plasma and the formation of autoantibodies. F. Immunol. 100, 682.

WeIL, A. J. (1961) Antigens of the adnexal glands of the male genital tract. Fert. Steril. 12, 538.

Weil, A. J. \& Finkler, A. E. (1958) Antigens of rabbit semen. Proc. Soc. exp. Biol. Med. 98, 794.

Weir, A. J., Kotsevalov, O. \& Wirson, L. (1956) Antigens of human seminal plasma. Proc. Soc. exp. Biol. Med. 92, 606.

Witson, L. (1954) Sperm agglutinins in human semen and blood. Proc. Soc. exp. Biol. Med. 85, 652. 